\title{
TEACHER EDUCATION - THE IMMEDIATE NEED FOR A POSITIVE TRANSFORMATION OF ENGINEERING EDUCATION IN INDIA
}

\author{
Paraitham Sreenivas Sarma $^{1}$, P. V. K. Sandeep ${ }^{2}$ \\ ${ }^{1}$ Civil Engineering Department, CBIT, Hyderabad, Telangana \\ ${ }^{2}$ Department of Electronics and Computer Engineering, SNIST, Hyderabad \\ 1paraithamsarma@gmail.com \\ ${ }^{2}$ sandeep5484@gmail.com
}

\begin{abstract}
It is often argued that the mushrooming growth of private engineering institutions in the country is primarily responsible for the diluted quality of engineering education in the country. Quite paradoxically, the number of engineering students in India, including both undergraduate and post graduate students is 1290 per million population which is the lowest rate in comparison among all the countries in the world. However, the fact remains that only about $25 \%$ of technical graduates are suitable for employment in the IT sector, and about $64 \%$ of the employers hiring the fresh graduates are only partially satisfied with the quality of graduates that they are getting. These facts establish that the engineering education in the country is suffering from dilution of quality.

This paper critically reviews the conditions of existing engineering institutions in the country, compares with the global data, identifies that the engineering education sector is in severe shortage of high quality faculty and establishes it as the main reason for the quality problems. It is proposed that the authorities at the helm of the affairs in deciding the policies in engineering education must focus on the qualitative aspects of teachers such as their performance and contributions to get the expected outcomes of the students, rather than insisting on the quantitative aspects of teachers such as higher qualifications, divisions / grades, number of publications, impact factors etc., which in no way would be directly contributing for the enhancement of quality of students . Finally, the paper highlights that the "Teacher Education" is the immediate need for bringing in a positive transformation in engineering education in India.
\end{abstract}

\footnotetext{
Paraitham Sreenivas Sarma

Professor, CED-CBIT, Hyderabad - 500075, Telangana

paraithamsarma@gmail.com
}

Keywords: Engineering education in India, Teacher Education, Transformation in Engineering Education

\section{Evolution of Engineering Education in India}

Indian education system finds it's traces way back during the Vedic period (prior to 1000 B.C.) and the Epic period (1000 B.C. to 800 B.C.). The teachings in those days included technological skills and science of war fare besides Vedas, languages, logics, ethics, philosophy, politics and economics. The country became a hub for Universities like Taxila , Nalanda , Ranchi ...where students from other countries used to come to study various subjects on arts, sciences, medicine and get trained to acquire numerous technical skills such as carpentry ,smithy , foundry and weaving. The excellence of temple sculpture , the elegance of various paintings, embroidery, weaponry like swords and knives, crockery, jewellery that has sustained over centuries right from the medieval period, would not have been possible without a dependable system of technical education and training in those days . During the British rule, land survey was given high priority to train the people to use sophisticated instruments to do survey works for the Government . The first Survey school was established in 1794 in Madras for this purpose. Thompson College was the first engineering college established in India in 1854 in honour of its founder. Presently, it is known as IIT, Roorkee .Intake to this college at that time was only in Civil Engineering. The teachers of this college did a pioneering job in the first twenty five years of its inception. They have systematized the teaching of engineering education by preparing the teaching material. The books and material published by the printing press of this college later became standard texts in other engineering colleges in the country.

\section{Present Status of Engineering Education in India}


The number of engineering institutions in the country has literally tripled in the last ten years; from about 1500 in 2005 to about 4500 in 2015 .About $95 \%$ of these are in the private sector. Most of these are lacking the required qualified staff, lab facilities and are not implementing the sixth pay to the faculty. Some of these institutions are already on the threat of becoming extinct in view of either the restrictions imposed by All India Council for Technical Education (AICTE) as part of their measures to refine the system or due to the poor admissions they received. In some of the states, the Governments have allowed a varied fee structure, giving priority to those institutions who are maintaining standards in terms of the infrastructure and the staff. Rankings of the institutions are also being practiced to encourage a healthy competition among the colleges.

In spite of several efforts from various corners, the facts and statistics from the engineering institutions are quite disgusting. According to NASSCOM survey, only about $25 \%$ of the students are employable in the IT jobs while about $64 \%$ of the employers are only partially satisfied with the graduates they are getting to work with them. This survey includes all those institutions including top ranked institutions like IITs, IIITs, NITs, University colleges and top ranked private institutions.

\section{Comparison of Indian Engineering Education with Global}

According to 2012 statistics, the Graduate enrolment ration in higher education in India is only $17.9 \%$ as compared with that of $26 \%$ in Brazil and China and $76 \%$ in Russia. The number of engineering students per million population of the country is only 1290, which is the lowest in the world. Private institutions in India share $83 \%$ of the engineering students while it is $0 \%, 2 \%$ and $21 \%$ respectively in UK, Russia and USA. The number of engineering faculty per institute is only 19 , the lowest in the world. The student faculty ratio in the engineering institutions of India is 24 , the highest in the world. This means that there is a huge short fall of faculty in the engineering institutions of the country. In the total number publications from the engineering institutions, India has bettered Brazil and Russia in 2010, while it is still far behind USA, UK, Japan and China. In terms of patents, India is again lowest in the world.

On the whole, the Indian scenario reflects clearly the poor quality of engineering education when compared to international status. It is needless to say that lack of faculty and facilities are the prime reasons for this. However, it may be noted that even in those institutions where qualified faculty and good facilities are available, the quality of Indian engineering students is still suffering. That means the delivery to the students is not properly happening. The existing system of evaluation of faculty and institutions by organizations like AICTE is unable to check this aspect, and hence needs a thorough revision.

\section{Features of the Existing System of Evaluation}

Including the newly introduced outcome based approach for evaluating the institutions; the methods adopted by the National Board of Accreditation (NBA) are mainly focusing on the qualifications \& publications of staff and end results called outcomes of the programme. It may be noted at this juncture that NBA or any such other evaluating body will only focus on quantitative aspects of teachers such as higher qualifications, divisions / grades, number of publications , impact factors etc., which in no way would be directly contributing for the enhancement of quality of students. Further, it just points out the level of the institution and it is not its job to rectify the mistakes done by the institution. Hence, it is for the institution to either maintain or raise its standards in order to realize its vision. This aspect primarily depends on the way things are delivered by the teachers. Thus, training the teachers of engineering institutions is an essential requirement for bringing in transformation in the engineering education. Nowhere this need is identified in the present system of evaluation

\section{Proposals for a New System}

For any system to be sustainable, it should go closer to a natural system. The system shall be highly accommodative inviting diversity among its ingredients. Teaching being a performing art, more preference / weightage shall be given for the performance of an individual as a teacher. While encouragement may be given to an individual for his / her qualification improvement, publications etc., the impact created by these deeds of a teacher in developing and motivating students should be duly recognized. Very often, the qualifications, grades/ divisions of an individual are considered to be the quality indices. In a performing profession like teaching, there is no direct relation between these aspects and students' quality. While a Ph.D. may be the recognition for an individual's effort, research is totally different activity which can engage several people together for a common cause.

Hence, in the new system, it is proposed to have weightage for the performance of an individual as a teacher and selfless contributions of a teacher to enhance the quality of a student. Teacher training must be given greater weightage.

\section{Conclusions}

Keeping in view the Indian scenario of engineering education, teacher education through appropriate training programs must be immediately taken up at large scale for bringing in positive transformation in engineering education.

\section{References}

1. National Science Academy , 2001, "Pursuit and promotion of Science “, pp .83-90

2. Report no.57, South Asia Human development centre, April 2013 “ International comparative : Engineering Education in India 